\author{
WOJCIECH SOSNOWSKI \\ Institute of Slavic Studies, Polish Academy of Sciences, Warsaw, Poland \\ wpsosnow@uw.edu.pl
}

\title{
FORMS OF ADDRESS AS DISCRETE MODAL OPERATORS
}

\begin{abstract}
The category of expressions of politeness includes, among others, forms of address. Forms of address express honorification. Honorification can be defined as a special type of meaning that consists of information about the social and interpersonal relations between the speaker and the addressee, the speaker and the hearer, and the speaker and the protagonist of the predication. As far as their place in the syntactic structure is concerned, forms of address can either be integrated with the other elements of a predication or not. However, they are always part of a predication's semantic structure. Moreover, forms of address convey the speaker's attitude to the meaning of the predicate that they want to convey, which consequently means that forms of address also carry a modal element. Modality can be defined as a situation in which an individual is in a particular mental state, i.e. exhibits some kind of attitude to a situation or a type of situations. Forms of address can be categorised as modal operators conveying imperatives, requests, suppositions, etc. The term "operator" can be used for a unit of language when it changes the semantic structure of the predication. My research on honorification is mainly based on contemporary corpora, both monolingual and multilingual. In the present study, I analyse forms of address which carry imperative and optative meanings.
\end{abstract}

Keywords: forms of address; honorification; modality; modal operators; parallel corpora

\section{Forms of address}

The category of expressions of politeness includes, among others, forms of address (Pol. formy adresatywne, Ger. adressative form, Span. formas apelativas, Rus. обращение, Bul. обрбщение). Forms of address belong to the most important means through which participants of interactions negotiate the relation that exists between themselves (cf. Kerbrat-Orecchioni, 2005). Forms of address are performative utterances which - through the use of pronominal forms or their equivalents, nominal forms and attributive forms (i.e. some possessive pronouns and some adjectives) enable the speaker to open a language interaction with the listener(s) and to maintain the interaction. They also allow interlocutors to determine the social status of the speaker in relation to the listener(s), in accordance with the social and cultural norms that determine the type and amount of distance between the participants of an act of communication. Forms of address indicate to whom an utterance is being addressed. Apart from this, they also encode the speaker's attitude towards the hearer. The speaker's attitude is determined by a number of different factors: the age hierarchy, the social hierarchy, the speaker's affective state, or the speaker's manners (Скоб- 
ликова, 2009, p. 280). Thus, forms of address are an inherent element of the semantic structure of a discourse.

\section{Honorification}

Huszcza's (2006) contrastive study on East Asian languages and Polish was the first to investigate honorification in Polish. Huszcza (2006, p. 47) defined honorification as "a special type of meaning in a discourse which encodes the information about the social relation between the speaker and the hearer of an utterance and about the speaker and the protagonist of the utterance". Honorification can be encoded both grammatically and lexically. The category (i.e. honorification) is present in many languages. In my research, I investigate the category of honorification in Slavic languages.

\section{Sources of data}

I have collected large amounts of language data by noting down interesting examples from conversations with native speakers and non-native speakers of Bulgarian, Polish and Russian. The utterances in those conversations were addressed directly at conversation partners. My subjects came from different professional backgrounds (students, intelligentsia, working class and farmers) and environments (urban and non-urban). Additional data came from dialogues in foreign language textbooks, as well as monolingual and bilingual dictionaries. The largest portion of my material comes from dialogues from the Polish-Bulgarian-Russian parallel corpus (Sosnowski, 2015b). Multiple text genres are included in the corpus: literary texts from the 19th, 20th and $21^{\text {st }}$ century, instruction manuals and technical documentation, legal texts, as well as other types of documents.

If we analyse the language data from the last two decades, we can see that the system of forms of address differs significantly from those of earlier years. The reason for the change in Russian, Bulgarian and Polish (as well as other Slavic languages) were the political transformations of the 1990s. For instance, the Polish word obywatelu! ('citizen!', Bul. гражданино! Rus. гражданин!) has gone out of use as a form of address. ${ }^{1}$ Another word that has gone out of use is the typical socialist form of address 'comrade': Pol. towarzyszu! Bul. другарю! Rus. поварищ! The changes pertain to both genders, therefore the female forms, e.g. Pol. obywatelko! '(female) citizen', towarzyszko! '(female) comrade', are no longer used either. The two changes above were of a lexical nature. However, grammatical forms have also undergone some transformations. In Polish, for instance, speakers ceased to use the second person plural forms when referring to one person, because in the new political reality this form was considered as ideologically loaded and thus unacceptable.

\section{Functors, modal functors, modal operators, discrete modal operators of forms of address}

In Kotarbiński's work (Kotarbiński, 1957), a functor refers to one of the three semantic categories. A functor is an expression that is neither a name nor a sentence. Functors are used to build more complex expressions: names, sentences and composite functors. The category of functors, names and sentences is different from the category of sentences, names, predicates and logical constants (operators and conjunctions). The latter category contains two types of functors: conjunctions and predicates. In the English-speaking tradition functors refer mainly to name-forming functors. It is said that sentence-forming functors form different types of sentences depending on the number of arguments that belong to those functors. A name-forming functor, in contrast, forms a new

\footnotetext{
${ }^{1}$ Its Russian equivalent гражданин! is still used by officials (e.g. police officers) when addressing people.
} 
name, e.g. a mother and a wife is a name composed of and and two arguments. The term functor has received multiple definitions in the literature - both narrow as well as broad. The type of functor I will use in this study is the extensional functor (synonymous with the truth functor). An extensional / truth functor in combination with its arguments forms an expression whose denotation depends only on the denotation of its arguments. In logic those are: negation, implication and conjunction. Since the denotation of a sentence is its truth value, the extensional functor stands in opposition to the intensional functor, whose truth value does not depend on the truth value of its argument(s), e.g. the truth value of "I think it's raining now" does not depend on the truth value of "it's raining now". This approach is present in Russell's (1967) direct reference semantics, Rasiowa's (1975) model and Gramatyka konfrontatywna butgarsko-polska (KoseskaToszewa \& Gargov, 1990; Koseska-Toszewa, 2006; Koseska-Toszewa, Korytkowska, \& Roszko, 2007). Ajdukiewicz (1985, pp. 223-242) demonstrated the difference between a functor and an operator: a functor can constitute an argument of another functor, whereas an operator cannot be an argument of a functor. What they have in common, however, is that an operator, along with the expressions they refer to, can create a composite whole with a unified meaning - similar to functors and their arguments.

The distinctive feature of an operator is its binding capabilities. In contrast to functors, operators can bind one or more variables. In terms of logic, the operator's definition is narrower to that of the functor. I will apply the notion of the operator to linguistics, because I would like to investigate its modal functions. I use the term operator in cases when it introduces alterations to the semantic structure of a sentence that reflect the speaker's attitude to what is being said. Operators facilitate the alterations because they bind them.

\section{Operators and modality}

Even though forms of address can be either integrated or not integrated with the syntactic structure of an utterance, they are always part and parcel of the semantic structure of a sentence. Weinrich (Вейнрейх, 1970, pp. 173-177) and Wierzbicka (Вежбицкая, 1982, p. 262) classify forms of address as a type of pragmatic operator. Weinrich suggested that all elements that express the attitude of the speaker towards what is being said as well as all elements that can be classified as pragmatic operators always "hinge" upon the predicate not the subject. Slavic languages have a large number of diminutive forms derived from proper names. Nevertheless, those diminutive forms are used in the expressive function only as forms of address. If a proper name is in the subject position, it usually takes its basic form (as opposed to diminutive). Should a diminutive form occur in the subject position, it loses its expressive function (Вежбицкая, 1982). In light of contemporary research on modality and the large amounts of data collected from parallel corpora and spoken language, we need to adopt a different approach to investigating the phenomenon. My research on forms of address is based on the principle that semantics and pragmatics are not two entirely separate modules - demarcating the exact boundaries between them is a theory-internal issue and as such it is beyond the scope of this paper.

In terms of the semantics of natural language, there are two types of mental states in relation to situation $\mathrm{P}$ : (1) knowing that $\mathrm{P}$, and (2) not knowing that $\mathrm{P}$ accompanied by some additional features (see Bogusławski, 1986, p. 259). Linguistic expressions conveying the former type is indicative modality, whereas expressions conveying the latter is non-indicative modality. Mental states of the latter type (2) can be further divided into subtypes that depend on which "additional features" are relevant to a given description (Bogusławski, 1986, p. 259). Those subtypes are also relevant to the semantic category of modality, because they determine the type of modality.

Direct reference semantics postulates that the mental state of knowing that $\mathrm{P}$ should be understood as: "a person is in such mental state that he/she exhibits a linguistic behaviour ${ }^{2}$ which corresponds to the behaviour of a person who experienced/observed P". Sentences in natural

\footnotetext{
${ }^{2}$ That is, the person formulates his/her utterances by using certain linguistic expressions.
} 
language which express such mental states are true. Analogically, the mental state of not knowing that $\mathrm{P}$ corresponds to sentences in natural language whose truth value is possibility. A modal operator occurs before a sentence and alters the meaning of the entire sentence and paragraph. Wierzbicka called this position the modal frame.

In conclusion, I see modality as ,,[A] Language category, which is a means of expression of the relationship between the speaker and the content of the statement. In natural languages, it typically has a grammatical paradigm called mode or mood (modus in Latin)" (Koseska-Toszewa \& Dimitrova, 2014).

\section{Imperative and optative modalities}

In this study, I will analyse imperative and optative forms of address. Following Koseska-Toszewa, Maldžieva, Penčev (1996, pp. 74, 76) I define imperativity $p !=I$ demand $p$ as modality expressing orders, whereas optativity $=I$ want $p$ is modality expressing wishes. The mental state of the speaker reflects the speaker's assessment of the information he/she is trying to convey. It occurs simultaneously with the state of the utterance, but always precedes the local state. The mental state of the speaker is directed at the recipient of the utterance. Optative and imperative modalities are related. One of the objects of a modal situation is (in the case of imperativity) or can be (in the case of optativity) the person whom we can name you - it is the addressee of the utterance. Both coercion and prohibition as well as requests and wishes are usually directed at another person and their purpose is to persuade somebody to carry out a desired action.

\section{$7 \quad$ Analysis of linguistic data}

The notion of usage situation is crucial for the analysis of the linguistic data I have collected. A usage situation is a situation when one person in a given spatial-temporal relation utters an expression and the expression is true. A usage situation concerns both the speaker and the addressee (Barwise \& Perry, 1983, p. 267). The languages I analyse in this study (i.e. Bulgarian, Polish and Russian) have a great variety of forms of address. Each form conveys a different type of relation between interlocutors, which are in turn dependent on the usage situation.

The data from parallel corpora suggest that forms of address can occur:

(a) at the beginning of a sentence

\begin{tabular}{|l|l|l|l|}
\hline $\begin{array}{l}\text { - Drogi Fagocie, bądź tak uprzej- } \\
\text { my i pokaż nam na początek coś } \\
\text { prościutkiego. }\end{array}$ & $\begin{array}{l}\text { Любезни Фагот, хайде, по- } \\
\text { простичко. }\end{array}$ & $\begin{array}{l}\text { - Скажи мне, любезный Фагот, } \\
\text { почало нещо по- }\end{array}$ \\
$\begin{array}{l}\text { покажи для начала что-нибудь } \\
\text { простенькое. }\end{array}$
\end{tabular}

M. Buthakow Master and Margarita (source: Parallel Polish-Bulgarian-Russian corpus, which is to be incorporated into the CLARIN framework)

(b) in the middle of a sentence

\begin{tabular}{|l|l|l|}
\hline $\begin{array}{l}\text { To są, mości panie, polskie } \\
\text { - Това са, уважаеми пане, пол- } \\
\text { ските пъъища. }\end{array}$ & Это, сударь, польские дороги. \\
\hline
\end{tabular}

S. Żeromski Ashes (source: Parallel Polish-Bulgarian-Russian corpus, which is to be incorporated into the CLARIN framework)

(c) at the end of a sentence

\begin{tabular}{|c|c|c|}
\hline $\begin{array}{l}\text { Teraz już jesteś panną, } \\
\text { moja mała. }\end{array}$ & Вече си девойка, дъще моя. & Ты стала взрослой, доченька. \\
\hline
\end{tabular}


Regardless of where the form of address appears in the surface structure of a sentence, in the semantic structure it is always the initial element; therefore, forms of address open a slot for modal operators of various types, e.g. optativity or imperativity:

(I)

Optativity $=\mathrm{X}$ (the speaker) speaks to $\mathrm{Y}$ (the addressee) using adequate linguistic means $(\mathrm{Z})$, so that the addressee $(\mathrm{Y})$ fulfils the request of the speaker $(\mathrm{X})$, e.g.

\begin{tabular}{|c|c|c|}
\hline $\begin{array}{l}\text { - (1) Łaskawy panie }- \text { ozwał } \\
\text { się Albert z kurtuazją pełną ser- } \\
\text { deczności }- \text { baron de Chateau- } \\
\text { Renaud przewidział, jaką sprawi } \\
\text { mi radość przyprowadzając } \\
\text { tu pana. Jesteś pan jego } \\
\text { przyjacielem, bądźże i naszym. }\end{array}$ & 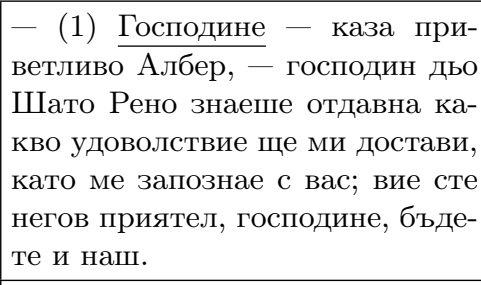 & $\begin{array}{l}\text { - (1) Господин Моррель, }- \text { ра- } \\
\text { душно сказал Альбер, - ба- } \\
\text { рон Шато-Рено заранее знал, } \\
\text { что доставит мне особенное удо- } \\
\text { вольствие, познакомив меня с } \\
\text { вами; вы его друг - надеюсь, вы } \\
\text { станете и нашим другом. }\end{array}$ \\
\hline $\begin{array}{l}\text { - Ślicznie to powiedziałeś - rzekł } \\
\text { Chateau-Renaud - i życzę ci, } \\
\text { (2) mój drogi, aby w podobnym } \\
\text { wypadku pan kapitan zrobił dla } \\
\text { ciebie to, co zrobił dla mnie. }\end{array}$ & $\begin{array}{l}\text { - Чудесно! - обади се Ша- } \\
\text { то Рено. - И пожелайте, (2) } \\
\text { драги виконте, да направи и за } \\
\text { вас това, което направи за мене. }\end{array}$ & $\begin{array}{l}\text { - Отлично, - сказал Шато- } \\
\text { Рено, - и пожелайте, }(2) \\
\text { дорогой виконт, чтобы в случае } \\
\text { нужды он сделал для вас то } \\
\text { же, что для меня. }\end{array}$ \\
\hline
\end{tabular}
A. Dumas The Count of Monte Cristo, Part 2 (source: Parallel Polish-Bulgarian-Russian corpus, which is to be incorporated into the CLARIN framework)

The utterance expressed by X contains the form of address (1) Easkawy panie / Госnодине / Господин Миррель = I want $\mathrm{Y}$ to become friends with $\mathrm{X}$

Linguistic means (Z): Pol. = Adj. (łaskawy 'kind') + N. (panie (Voc.) 'Mister/Sir') / Bul. = Noun (Господине (Voc.) 'Mister/Sir') / Rus. N. (Господин (Nom.) 'Mister/Sir') + N. Surname (Миррель (Nom.)). The linguistic means $\mathrm{Z}$ analysed here show that the form of address in each language is in keeping with the cultural norms and norms of politeness characteristic for a given language. Nevertheless, regardless of the choice of linguistic means the speaker always expresses a wish which can be paraphrased as "I wish that".

In (2) the speaker used the form mój drogi / драги виконте / дорогой виконт 'Dear Viscount', because the speaker $(\mathrm{X})$ would like the addressee $(\mathrm{Y})$ to fulfil his wish.

(II)

In (3) the speaker used the form (Z) Drogi Fagociе / Любезни Фагот / любезный Фагот 'Dear Fagot', because the speaker (X) wants the addressee (Y) to show something to $(\mathrm{X})$ and would like this wish to be fulfilled.

\begin{tabular}{|c|c|c|}
\hline 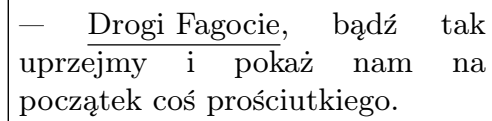 & $\begin{array}{l}\text { - Любезни Фагот, хайде, по } \\
\text { кажи ни за начало нещо по } \\
\text { простичко. }\end{array}$ & $\begin{array}{l}\text { - Скажи мне, любезный Фагот, } \\
\text { покажи для начала что-нибудь } \\
\text { простенькое. }\end{array}$ \\
\hline
\end{tabular}

M. Bułhakow Master and Margerita (source: Parallel Polish-Bulgarian-Russian corpus, which is to be incorporated into the CLARIN framework)

(III)

The speaker (X) used the form (Z) Babciu / Бабо / Бабушка 'Granny', because the speaker (X) wants the addressee (Y) to give something to $(\mathrm{X})$ and would like this wish to be fulfilled.

\begin{tabular}{|l|l|l|l|}
\hline - Babciu, daj mi szafkę. Nie & - Дай ми бабо, дай ми едно & - Бабушка, дай мне какой- \\
mam gdzie schować swojego \\
elementarza!
\end{tabular}
G. Karaslavov Uczone myszy (source: Parallel Polish-Bulgarian-Russian corpus, which is to be incorporated into the CLARIN framework) 
(IV)

The speaker (X) used the form (Z) mój przyjacielu / приятелю / мой любезный друг 'my friend', because the speaker $(\mathrm{X})$ wants the addressee $(\mathrm{Y})$ to become happy that he sees $(\mathrm{X})$ and (X) would like this wish to be fulfilled.

\begin{tabular}{|c|c|c|}
\hline $\begin{array}{l}\mathrm{m}, \text { Old } \\
\text { yjacielu, } \mathrm{k} \\
\text { serca, }\end{array}$ & $\begin{array}{l}\text { И тъй, Олд Шетърхенд, } \\
\text { приятелю, спечелил цялата ми } \\
\text { любов, ти си възхитен, че ме } \\
\text { виждаш пак, нали? }\end{array}$ & $\begin{array}{l}\text { Мо } \\
\text { нул } \\
\text { это }\end{array}$ \\
\hline
\end{tabular}

K. May, Winnetou (source: Parallel Polish-Bulgarian-Russian corpus, which is to be incorporated into the CLARIN framework)

In sentences (I-IV) speakers want to fulfil their wishes using various linguistic means. Let us consider a situation when speakers use completely opposite expressions, which are still coherent with the rest of the discourse:

I Instead of Laskawy panie 'Kind sir' (Z') = Okropny człowieku 'You horrible man'

II Instead of Drogi Fagocie 'Dear Fagot' (Z') = Idioto 'You idiot'

III Instead of Babciu 'Granny' (Z') = Stara babo 'You old hag'

IV Instead of Mój przyjacielu 'My friend' (Z') = Obywatelu 'Citizen'.

It is more than likely that if $(\mathrm{X})$ used the alternative forms of address ( $\left.Z^{\prime}\right)$, his wish would not be fulfilled by the addressee $(\mathrm{Y})$.

Let us analyse discrete modal operators of imperativity.

(ii) imperativity $=\mathrm{X}$ (the speaker) speaks to $\mathrm{Y}$ (the addressee) using adequate linguistic means (Z), so that the addressee (Y) fulfils the order of the speaker $(\mathrm{X})$, e.g.

(I)

The speaker (X) used the form (Z) Towarzyszu (Bezdomny) / Другарю (Бездомни) / Товарищ, (Безодмныци) 'Comrade (Homeless)', because the speaker (X) orders the addressee (Y) to calm down.

\begin{tabular}{|c|c|c|}
\hline $\begin{array}{l}\text { - Towarzyszu Bezdomny - po- } \\
\text { wiedziała ta twarz jubileuszowym } \\
\text { głosem - uspokójcie się! }\end{array}$ & $\begin{array}{l}\text { - Другарю Бездомни - загово- } \\
\text { ри лицето с юбилеен глас, - } \\
\text { успокойте се! }\end{array}$ & $\begin{array}{l}\text { - Товарищ Бездомный, - заго- } \\
\text { ворило это лицо юбилейным го- } \\
\text { лосом, - успокойтесь! }\end{array}$ \\
\hline
\end{tabular}
M. Buthakow Master and Margerita (source: Parallel Polish-Bulgarian-Russian corpus, which is to be incorporated into the CLARIN framework)

(II)

The speaker (X) used the form (Z) Тоwarzyszu (dyżrny) / Другарю дежурен / Товарищи дежурный 'Comrade (duty officer)', because the speaker (X) orders the addressee (Y) to dispatch motorcycles.

\begin{tabular}{|c|c|c|}
\hline$\frac{n y}{\text { lać }}$ pięć $n$ & $\begin{array}{l}\text { Цругарю дежурен, } \\
\text { ъдат пратени нез } \\
\text { гоцоциклета с кар } \\
\text { алавянето на чуж }\end{array}$ & $\begin{array}{l}\text { Товарищ дежурный, pa } \\
\text { рядитесь сейчас же, ч } \\
\text { выслали пять мотоцикл } \\
\text { с пулеметами для по }\end{array}$ \\
\hline
\end{tabular}

M. Buthakow Master and Margerita (source: Parallel Polish-Bulgarian-Russian corpus, which is to be incorporated into the CLARIN framework)

(III)

The speaker (X) used the form (Z) Obywatelu / Гражданино / Гражданин 'Citizen', because the speaker $(\mathrm{X})$ orders the addressee $(\mathrm{Y})$ to allow $(\mathrm{X})$ perform a personal search on $(\mathrm{Y})$. 
A. Wagenstein Far from Toledo (source: Parallel Polish-Bulgarian-Russian corpus, which is to be incorporated into the CLARIN framework)

(IV)

The speaker (X) used the form (Z) Obywatelu (Wartanian) / Гражданино Вартанян / господин Вартанян 'Citizen (Vartanian)', because the speaker (X) orders the addressee (Y) to remain at his disposal.

\begin{tabular}{|l|l|l|}
\hline $\begin{array}{l}\text { Zaś wy, obywatelu Wartanian, na } \\
\text { razie zostaniecie do naszej dyspo- } \\
\text { zycji. }\end{array}$ & $\begin{array}{l}\text { А вие, гражданино Вартанян, } \\
\text { ще останете засега на наше раз- } \\
\text { положение. }\end{array}$ & $\begin{array}{l}\text { А вы, господин Вартанян, пока } \\
\text { что останетесь в нашем распо- } \\
\text { ряжении. }\end{array}$ \\
\hline
\end{tabular} A. Wagenstein Far from Toledo (source: Parallel Polish-Bulgarian-Russian corpus, which is to be incorporated into the CLARIN framework)

In sentences (I-IV) speakers demand that their addressees fulfil their orders using various linguistic means. Let us consider a situation when speakers use completely opposite expressions, which are still coherent with the rest of the discourse:

(I) Zamiast Towarzyszu (Bezdomny) 'Comrade (homeless)' (Z') = Kochanie 'Honey'

(II) Zamiast Towarzyszu (dyżurny) 'Comrade (duty officer)' (Z') = Mój drogi 'My dear'

(III) Zamiast Obywatelu 'Citizen' (Z') = Bracie 'Brother'

(IV) Zamiast Obywatelu (Wartanian) 'Citizen (Vartanian)' (Z') = Najdroższy 'Dear Vartanian'

It is more than likely that if (X) used the alternative forms of address (Z'), his order would not be fulfilled by the addressee (Y). The linguistic means $(\mathrm{Z})$ used in sentences (I-IV) above are composed of a form of address and a verb in second person plural. In Polish, this form has gone out of use, because in the new political reality it was considered as ideologically loaded and thus unacceptable.

\section{Conclusions}

The data analysed here show that forms of address express the attitude of a speaker towards the message he/she tries to convey to the addressee, hence they have a modal value. The term operator is used in logic and linguistics for situations in which it introduces changes to the semantic structure of a sentence. I categorise forms of address as discrete modal operators, because they also introduce changes to sentences through meanings such as: I wish or I demand.

The analysis of discrete modal operators of imperativity and optativity leads to the conclusion that most forms of address convey modalities expressing wishes and orders. This subject offers multiple avenues for future research; for instance, the modal operators of hypotheticality, imperceptivity, unreality, conditionality and interrogation still remain relatively unexplored. We know that many forms of address are of neutral or mixed nature. However, they are always part and parcel of the semantic structure of a sentence and they determine the rest of the discourse that ensues. 


\section{References}

Ajdukiewicz, K. (1974). Logika pragmatyczna. Warszawa: PWN.

Ajdukiewicz, K. (1985). Język i poznanie (Vol. 1). Warszawa: PWN.

Barwise, J. \& Perry, J. (1983). Situations and attitudes. Cambridge, MA: Branfordbooks, MIT.

Boguławski, A. (1986). Analiza zdań warunkowych a problem funkcji semiotycznych. Studia Semiotyczne, $14-15,215-224$.

Duszkin, M. (2014). Praktyczny przewodnik po korpusie języka rosyjskiego. In M. Hebal-Jezierska (red.) Praktyczny przewodnik po korpusach języków słowiańskich, s. 142-165. Warszawa.

Duškin, M. \& Satoła-Staśkowiak, J. (2011). The Bulgarian-Polish-Russian Parallel Corpus, Cognitive Studies / Études cognitives, 11, 241-254. DOI: http://dx.doi.org/10.11649/cs.2011.015

Huszcza, R. (2006). Honoryfikatywność. Gramatyka. Pragmatyka. Typologia. Warszawa: PWN.

Jaskot, M. (2014). Relaciones semánticas entre homónimos interlingüísticos. In J. Pawlik \& J. Szałek (Eds.), Lingüística española en Polonia: Lineas de investigación (pp. 83-90). Poznań: Wydawnictwo Naukowe Uniwersytetu im. Adama Mickiewicza.

Kisiel, A., Koseska-Toszewa, V., Kotsyba, N., Satoła-Staśkowiak, J., \& Sosnowski, W. (2016). PolishBulgarian-Russian Parallel Corpus, CLARIN-PL digital repository. http://hdl.handle.net/11321/ 308

Kerbrat-Orecchioni, C. (2005). Le discours en interaction. Paris: Armand Colin.

Koseska-Toszewa, V. (2006). Gramatyka konfrontatywna bułgarsko-polska (Vol. 7, Semantyczna kategoria czasu). Warszawa: Slawistyczny Ośrodek Wydawniczy.

Koseska-Toszewa, V. \& Dimitrova, L. (2014). Semantic properties of selected universal language categories in digital bilingual resources. Sofia: DOVIRA Publ. House.

Koseska-Toszewa, V., Korytkowska, M., \& Roszko, R. (2007). Polsko-bułgarska gramatyka konfrontatywna. Warszawa: Wydawnictwo Akademickie Dialog.

Koseska-Toszewa, V., Maldžieva, V., \& Penčev, J. (1996). Gramatyka konfrontatywna bułgarsko-polska (Vol. 6-1, Modalność. Problemy teoretyczne). Warszawa: Slawistyczny Ośrodek Wydawniczy.

Koseska-Toszewa, V., Satoła-Staśkowiak, J., \& Sosnowski, W. (2013). From the problems of dicionaries and multi-lingual corpora. Cognitive Studies / Études cognitives, (13), 113-122. DOI: http://doi. org/10.11649/cs.2013.007

Kotarbiński, J. (1957). Wykłady z dziejów logiki. Łódź: Zakład Narodowy im. Ossolińskich.

Rasiowa, H. (1975). Wstęp do matematyki wspótczesnej. Warszawa: PWN.

Roszko, D. (2015). Zagadnienia kwantyfikacyjne i modalne w litewskiej gwarze puńskiej. (Na tle literackich języków polskiego i litewskiego), pp. 342. Warszawa: Instytut Slawistyki Polskiej Akademii Nauk.

Roszko, D. \& Roszko, R. (2016). Polish-Lithuanian Parallel Corpus, CLARIN-PL digital repository. http: //hdl.handle.net/11321/309

Roszko, R. (2012). Lexical exponents of hypothetical modality in Polish and Lithuanian.

Cognitive Studies / Études cognitives, 12, 15-25. DOI: http://dx.doi.org/10.11649/cs.2012.001

Russel, B. (1967). Denotowanie, deskrypcje. In J. Pelc (Ed.), Logika i język (pp. 259-293). Warszawa: PWN.

Satoła-Staśkowiak, J. (2015). On the benefits of foreign language learning based on parallel language corpus. Cognitive Studies / Études Cognitives, 15, 57-65. DOI: http://dx.doi.org/10.11649/cs. 2015.005

Sosnowski, W. (2013). Forms of address and their meaning in contrast in Polish and Russian languages. Cognitive Studies / Études cognitives, 13, 225-235. http://doi.org/10.11649/cs.2013.015

Sosnowski, W. (2015a). Formy adresatywne — aspekt językowy i socjologiczny. In Semantyka $i$ konfrontacja językowa tom 5 (pp. 319-332). Warszawa: Slawistyczny Ośrodek Wydawniczy.

Sosnowski, W. (2015b). Parallel corpora, multilingual equivalents and digital translations. In B. BorkowskaKępska, G. Gwóźdź, \& P. Mamet (Eds.), LSP Perspectives (pp. 151-164). Dąbrowa Górnicza: The University of Dąbrowa Górnicza.

Sosnowski, W. (2016). The parallel Polish-Bulgarian-Russian corpus: Problems and solutions. In G. Corpas Pastor (Ed.), Computerised and corpus-based approaches to phraseology: Monolingual and multilingual perspectives (Full papers) [Fraseología computacional y basada en corpus: perspectivas monolingües y multilingües (Trabajos completos)] (pp. 339-349). Geneva: Tradulex.

Tomiczek, E. (1983). System adresatywny wspótczesnego języka polskiego i niemieckiego: Socjolingwistyczne studium konfrontatywne. Wrocław: Uniwersytet Wrocławski. 
Tomiczek, E. (1992). Z badań nad istotą grzeczności językowej. In J. Anusiewicz \& M. Marcjanik (Eds.), Język a kultura (Vol. 6, Polska etykieta językowa). Wrocław: Wiedza o Kulturze.

Вежбицкая, А. (1982). Дескрипция или цитация. In Новое в зарубежной лингвистике (Vol. 13). Москва: Радуга.

Вейнрейх, У. (1970). О семантической структуре языка. In Новое в лингвистике (Vol. 5). Mосква: Прогресс.

Скобликова, Е. (2009). Современный русский язык: Синтаксис простого предложения. Москва.

Яскот, М. (2009). Общественный образ в коммуникации: Участие или автономия? In Язык, культура, коммуникация: Материаль научно-практической конферениии (Рt. 2). Ижевск: Изд-во «дмуртский Университет».

Косеска-Тошева, В. \& Гаргов, Г. (1990). Българско-полска съпоставителна граматика, том 2. Семантичната категория определеност/неопределент, София.

\section{References (Transliteration)}

Ajdukiewicz, K. (1974). Logika pragmatyczna. Warszawa: PWN.

Ajdukiewicz, K. (1985). Język i poznanie (Vol. 1). Warszawa: PWN.

Barwise, J. \& Perry, J. (1983). Situations and attitudes. Cambridge, MA: Branfordbooks, MIT.

Boguławski, A. (1986). Analiza zdań warunkowych a problem funkcji semiotycznych. Studia Semiotyczne, 14-15, 215-224.

Huszcza, R. (2006). Honoryfikatywność. Gramatyka. Pragmatyka. Typologia. Warszawa: PWN.

Duszkin, M. (2014). Praktyczny przewodnik po korpusie języka rosyjskiego. [w:] M. Hebal-Jezierska (red.) Praktyczny przewodnik po korpusach języków słowiańskich, s. 142-165. Warszawa.

Duškin, M. \& Satoła-Staśkowiak, J. (2011). The Bulgarian-Polish-Russian Parallel Corpus, Cognitive Studies / Études cognitives, 11, 241-254. DOI: http://dx.doi.org/10.11649/cs.2011.015

IAskot, M. (2009). Obshchestvennyı̌ obraz v kommunikatsii: Uchastie ili avtonomiia? In IAzyk, kul'tura, kommunikatsiia: Materialy nauchno-prakticheskő konferentsii (Pt. 2). Izhevsk: Izd-vo «Udmurtskiı̆ Universitet».

Jaskot, M. (2014). Relaciones semánticas entre homónimos interlingüísticos. In J. Pawlik \& J. Szałek (Eds.), Lingüística española en Polonia: Líneas de investigación (pp. 83-90). Poznań: Wydawnictwo Naukowe Uniwersytetu im. Adama Mickiewicza.

Kisiel, A., Koseska-Toszewa, V., Kotsyba, N., Satoła-Staśkowiak, J., \& Sosnowski, W. (2016). PolishBulgarian-Russian Parallel Corpus, CLARIN-PL digital repository. http://hdl.handle.net/11321/ 308

Kerbrat-Orecchioni, C. (2005). Le discours en interaction. Paris: Armand Colin.

Koseska-Toszewa, V. (2006). Gramatyka konfrontatywna bułgarsko-polska (Vol. 7, Semantyczna kategoria czasu). Warszawa: Slawistyczny Ośrodek Wydawniczy.

Koseska-Toszewa, V. \& Dimitrova, L. (2014). Semantic properties of selected universal language categories in digital bilingual resources. Sofia: DOVIRA Publ. House.

Koseska, V. \& Gargov, G. (1990). Bŭlgarsko-polska sŭpostavitelna gramatika, tom 2. Semantichna kategoriia opredelenost/neopredelenost, Sofiia.

Koseska-Toszewa, V., Korytkowska, M., \& Roszko, R. (2007). Polsko-bułgarska gramatyka konfrontatywna. Warszawa: Wydawnictwo Akademickie Dialog.

Koseska-Toszewa, V., Maldžieva, V., \& Penčev, J. (1996). Gramatyka konfrontatywna bułgarsko-polska (Vol. 6-1, Modalność. Problemy teoretyczne). Warszawa: Slawistyczny Ośrodek Wydawniczy.

Koseska-Toszewa, V., Satoła-Staśkowiak, J., \& Sosnowski, W. (2013). From the problems of dicionaries and multi-lingual corpora. Cognitive Studies / Études cognitives, 13, 113-122. DOI: http://doi.org/ $10.11649 /$ cs. 2013.007

Kotarbiński, J. (1957). Wykłady z dziejów logiki. Łódź: Zakład Narodowy im. Ossolińskich.

Rasiowa, H. (1975). Wstęp do matematyki wspótczesnej. Warszawa: PWN.

Roszko, D. (2015). Zagadnienia kwantyfikacyjne i modalne w litewskiej gwarze puńskiej. (Na tle literackich języków polskiego i litewskiego), pp. 342. Warszawa: Instytut Slawistyki Polskiej Akademii Nauk.

Roszko, R. (2012). Lexical exponents of hypothetical modality in Polish and Lithuanian. Cognitive Studies / Études cognitives, 12, 15-25. DOI: http://dx.doi.org/10.11649/cs.2012.001

Roszko, D. \& Roszko, R. (2016). Polish-Lithuanian Parallel Corpus, CLARIN-PL digital repository. http://hdl.handle.net/11321/309 
Russel, B. (1967). Denotowanie, deskrypcje. In J. Pelc (Ed.), Logika i język (pp. 259-293). Warszawa: PWN.

Satoła-Staśkowiak, J. (2015). On the benefits of foreign language learning based on parallel language corpus, Cognitive Studies / Études Cognitives, 15, p. 57-65. DOI: http://dx.doi.org/10.11649/cs. 2015.005

Skoblikova, E. (2009). Sovremenny̆ russkiı iazyk: Sintaksis prostogo predlozheniia. Moskva.

Sosnowski, W. (2013). Forms of address and their meaning in contrast in Polish and Russian languages. Cognitive Studies / Études cognitives, 13, 225-235. DOI: http://doi.org/10.11649/cs.2013.015

Sosnowski, W. (2015a). Formy adresatywne - aspekt językowy i socjologiczny. In Semantyka $i$ konfrontacja językowa tom 5 (pp. 319-332). Warszawa: Slawistyczny Ośrodek Wydawniczy.

Sosnowski, W. (2015b). Parallel corpora, multilingual equivalents and digital translations. In B. BorkowskaKępska, G. Gwóźdź, \& P. Mamet (Eds.), LSP Perspectives (pp. 151-164). Dąbrowa Górnicza: The University of Dąbrowa Górnicza.

Sosnowski, W. (2016). The parallel Polish-Bulgarian-Russian corpus: Problems and solutions. In G. Corpas Pastor (Ed.), Computerised and corpus-based approaches to phraseology: Monolingual and multilingual perspectives (Full papers) [Fraseología computacional y basada en corpus: perspectivas monolingües y multilingües (Trabajos completos)] (pp. 339-349). Geneva: Tradulex.

Tomiczek, E. (1983). System adresatywny wspótczesnego języka polskiego i niemieckiego: Socjolingwistyczne studium konfrontatywne. Wrocław: Uniwersytet Wrocławski.

Tomiczek, E. (1992). Z badań nad istotą grzeczności językowej. In J. Anusiewicz \& M. Marcjanik (Eds.), Język a kultura (Vol. 6, Polska etykieta językowa). Wrocław: Wiedza o Kulturze.

Vel̆nreı̆kh, U. (1970). O semanticheskoŭ strukture iazyka. In Novoe v lingvistike (Vol. 5). Moskva: Progress.

Vezhbitskaia, A. (1982). Deskriptsiia ili tsitatsiia. In Novoe v zarubezhnoй lingvistike (Vol. 13). Moskva: Raduga.

\section{Acknowledgment}

This work was supported by a core funding for statutory activities from the Polish Ministry of Science and Higher Education.

The author declares that he has no competing interests.

This is an Open Access article distributed under the terms of the Creative Commons Attribution 3.0 PL License (http://creativecommons.org/licenses/by/3.0/pl/), which permits redistribution, commercial and noncommercial, provided that the article is properly cited.

\section{(C) The Author 2016}

Publisher: Institute of Slavic Studies, Polish Academy of Sciences, University of Silesia \& The Slavic Foundation 